\title{
REVIEW ARTICLES
}

\section{Pharmacological Therapy in Smoking Cessation MANZOOR MAHMOOD, HARISUL HOQUE, MD MUKHLESUR RAHMAN, SM MUSTAFA ZAMAN, MD ABU SALIM, JAHANARA ARZU, DIPAL KRISHNA ADHIKARY}

Department of Cardiology, Bangabandhu Sheikh Mujib Medical University (BSMMU)

Address for Correspondence: Dr. Manzoor Mahmood, Associate Professor, Department of Cardiology, BSMMU, Dhaka. Email-gudu65@gmail.com

\section{Introduction:}

Cigarette smoking is largely a $20^{\text {th }}$-century phenomenon. The introduction and promotion of manufactured cigarettes changed the nature of tobacco use to that of a regular consumer activity. The introduction of cigarettes is important from public health point of view due to 2 important reasons: ${ }^{17}$

1) The cigarette smoke is directly, deliberately inhaled.

2) As cigarettes are portable and convenient, tobacco smoking became a social and everyday phenomenon rather than a ceremonial and formal activity.

Regular use of cigarettes quickly leads to addiction. Tobacco smoke has been classified as a class A carcinogen ${ }^{7}$. The main components of tobacco smoke are:

1) Tar: As a solid irritant, tar coats the lungs, blocks the airways and causes emphysema and lung cancer.

2) Carbon monoxide (CO): $\mathrm{CO}$ binds to haemoglobin $\mathrm{Hb}$ ) and replaces oxygen. It causes heart and arterial disease. The level of CO in a smoker's body depends on the number of cigarette smoked and how they are smoked.

3) Nicotine: This is the addictive component of tobacco smoke. The nicotine in each puff of inhaled smoke reaches the brain in less than 7 seconds. The amount available in nicotine replacement therapy (NRT) is not sufficient to cause major physical harm.

Smoking is the chief avoidable cause of premature death and ill health in the world. It continues to be the dominant risk factor for cardiovascular disease (CVD) in terms of both mortality and morbidity. The total number of smokers is expected to reach about 1.6 billion by $2025 .{ }^{16}$ The cardiovascular effects are related to the amount of tobacco smoked daily and to the duration of smoking. In presence of other risk factors (diabetes, hypertension, dyslipidaemia, overweight) smoking related risk increases even further.

Smoking has been identified as the most important of the known modifiable risk factors for CVD. The death rate for all CVD for smokers is 2-3 times that of non-smokers and between $35 \%$ and $40 \%$ of these deaths occur before retirement age. ${ }^{24}$ Passive smoking increases the risk of heart disease by 23\% (Independent Scietific Committee on Smoking and Health. ${ }^{13}$

\section{Smoking cessation strategies:}

Given the ongoing risk for major cardiovascular events as defined in population-based studies, repeated clinical interventions to address chronic users and relapses seems very important. Effective pharmacologic and counseling strategies are now the pillars of tobacco cessation programmes. Currently approved $1^{\text {st }}$-line pharmacological agents include nicotine replacement therapy (NRT), which is available in different formulations; bupropion, an atypical antidepressant, and varenicline, a partial agonist of the $\alpha 4 \beta 2$ nicotinic acetylcholine receptor receptor.

In the following section pharmacological strategies involving 2 drugs (NRT and varenicline) will be discussed in general with particular emphasis on their effectiveness and safety on patients with cardiovascular disease or those at high risk of developing cardiovascular disease.

\section{Nicotine Replacement Therapy (NRT):}

Nicotine addiction leads to alteration of brain structure with nicotinic receptor upregulation, changes in brain activity evidenced by alteration regional glucose metabolism and cognitive effects that patient rely on such as mood and sleep control. ${ }^{9}$ The NRTs enable the person to abstain from by replacing the nicotine derived from their tobacco product use. The main 3 mechanisms NRTs can aid smoking cessation effort are: ${ }^{12}$

1) Physical withdrawal symptoms may be reduced.

2) It may also reduce the addiction enforcing effects of tobacco derived nicotine

3) It also helps by avoiding the mood disturbances and attention states of withdrawal. 

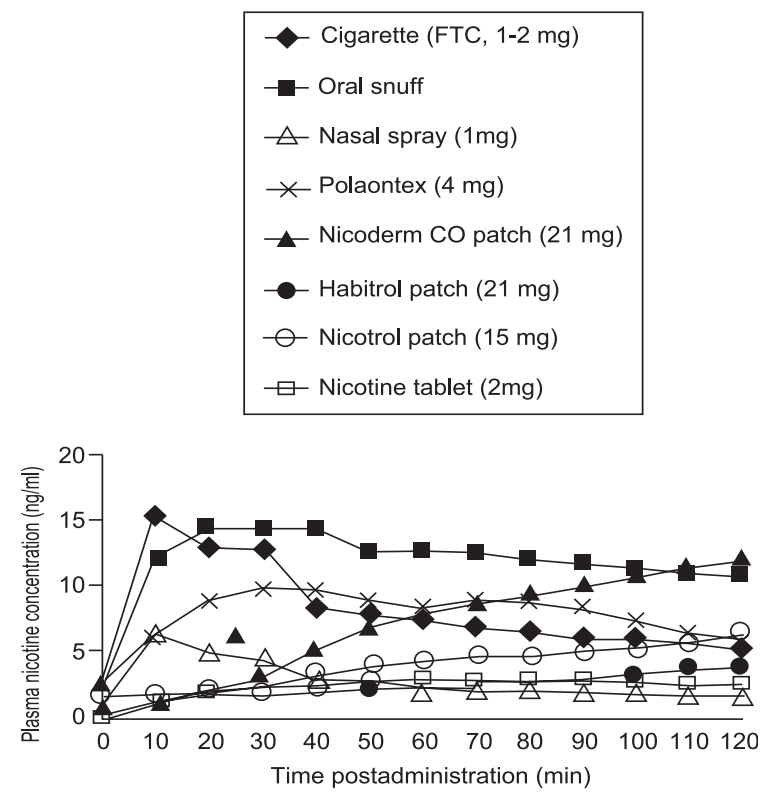

Fig.-1: Venous blood concentrations for various nicotine delivery products (Garrett \& Rose and Henningfield, 2001)

The above figure (Fig 1) shows none of the NRTs can elevate blood nicotine levels as quickly as inhaled cigarette smoke. The average systemic nicotine intake from cigarettes is $30 \mathrm{mg} / \mathrm{day}$. For example, a nicotine gum provided in a 2 to $4 \mathrm{mg}$ tablet usually provides $10 \mathrm{mg}$ or $20 \mathrm{mg}$ respectively.

Relative efficacy of different NRT formulations: ${ }^{27}$

Table-I

Risk Ratio (RR) of abstinence with different NRT

\begin{tabular}{ll}
\hline Treatment & Risk Ratio (95\% CI) \\
$\begin{array}{l}\text { NRT: All forms, pooled } \\
\text { (meta-analysis of 111 studies) }\end{array}$ & $1.58(1.50-1.66)$ \\
Gum & $1.43(1.33-1.53)$ \\
Patch & $1.66(1.53-1.81)$ \\
Inhaler & $1.90(1.36-2.67)$ \\
Lozenge & $2.00(1.63-2.45)$ \\
Nasal spray & $2.02(1.49-3.73)$ \\
\hline
\end{tabular}

The above table (Table 1) shows the efficacy of different NRT in clinical trials. It appears that all forms of NRT has more or less similar efficacy. This meta-analysis shows that NRTs increase the rate of quitting by $50-70 \%$, regardless of setting. The effects were largely independent of the duration of therapy.

Table-II

Different NRT formulations: Comments, adverse effects, contraindications and dosage (Nides, 2008)

\begin{tabular}{|c|c|c|c|c|}
\hline Medication & Comments & $\begin{array}{l}\text { Most Common } \\
\text { Adverse Events }\end{array}$ & Contraindications/Precautions & Dosage \\
\hline $\begin{array}{l}\text { Nicotine } \\
\text { patch }\end{array}$ & $\begin{array}{l}\text { FDA-approved } \\
\text { for smoking } \\
\text { cessation } \\
\text { Continuous- } \\
\text { release (long- } \\
\text { acting) } \\
\text { formulation } \\
\text { Available } \\
\text { OTCCan be } \\
\text { worn for } 24 \mathrm{hr} \\
\text { or for only } 16 \mathrm{hr} \\
\text { to avoid } \\
\text { insomnia }\end{array}$ & $\begin{array}{l}\text { Mild skin } \\
\text { irritation at } \\
\text { placement site }\end{array}$ & $\begin{array}{l}\text { Pregnancy category D; avoid in pregnant } \\
\text { women due to continuous delivery } \\
\text { formulation } \\
\text { Use with caution in acute cardiovascular } \\
\text { conditions, such as recent AMI; however, } \\
\text { risk-benefit ratio may be favorable in those } \\
\text { patients who continue to smoke }\end{array}$ & $\begin{array}{l}>10 \text { cigarettes/ } \\
\text { day: } 21 \mathrm{mg} / 24 \\
\text { hr for } 6-8 \mathrm{wk} \text {; } \\
\text { decrease to } 14 \\
\mathrm{mg} / 24 \mathrm{hr} \text { for } \\
2-4 \mathrm{wk} \text {; then to } \\
7 \mathrm{mg} / 24 \mathrm{hr} \text { for } \\
2-4 \mathrm{wk} \\
\leq 10 \text { cigarettes/ } \\
\text { day: } 14 \mathrm{mg} / 24 \\
\text { hr for } 6 \text { wk; } \\
\text { then decrease to } \\
7 \text { mg/24 hr for } \\
2-4 \text { wk }\end{array}$ \\
\hline
\end{tabular}




\begin{tabular}{|c|c|c|c|c|}
\hline Medication & Comments & $\begin{array}{l}\text { Most Common } \\
\text { Adverse Events }\end{array}$ & Contraindications/Precautions & Dosage \\
\hline Nicotine gum & $\begin{array}{l}\text { FDA-approved } \\
\text { for smoking } \\
\text { cessation } \\
\text { SANRT } \\
\text { formulation } \\
\text { allows for } \\
\text { flexible dosing } \\
\text { Available OTC } \\
\text { Heavy smokers } \\
\text { achieve greater } \\
\text { benefit with 4- } \\
\text { mg gum than 2- } \\
\text { mg gum (see } \\
\text { Dosage) } \\
\text { Shown to } \\
\text { reduce or delay } \\
\text { weight gain }\end{array}$ & $\begin{array}{l}\text { Jaw pain, } \\
\text { mouth soreness, } \\
\text { dyspepsia, } \\
\text { hiccoughs }\end{array}$ & $\begin{array}{l}\text { Pregnancy category C; the risk-benefit ratio } \\
\text { may be favorable in pregnant smokers if } \\
\text { efforts to quit without medication have } \\
\text { failed and if the patient is continuing to } \\
\text { smoke more than } 10-15 \text { cigarettes/dayAvoid } \\
\text { in patients with temporomandibular joint } \\
\text { diseaseUse with caution in acute } \\
\text { cardiovascular conditions, such as recent } \\
\text { AMI; however, risk-benefit ratio may be } \\
\text { favorable in those patients who continue to } \\
\text { smoke }\end{array}$ & $\begin{array}{l}\geq 25 \text { cigarettes/day: } \\
\text { use } 4 \text { mg nicotine } \\
\text { gum; <25 } \\
\text { cigarettes/day: use } \\
2 \text { mg nicotine gum } \\
\text { on the following } \\
\text { schedule: day } 1 \text { of } \\
\text { abstinence through } \\
\text { week 6: } 1 \text { piece } \\
\text { every } \\
1-2 \text { hr; weeks 7-9: } \\
1 \text { piece every 2-4 } \\
\text { hr; weeks } 10-12: \\
1 \text { piece every } \\
4-8 \text { hrIt is } \\
\text { suggested to use } \\
\text { e”9 pieces/day for } \\
\text { the first } 6 \text { wk } \\
\text { (max: } 20-30 \\
\text { pieces/day) }\end{array}$ \\
\hline Nicotine inhaler & $\begin{array}{l}\text { FDA-approved } \\
\text { for smoking } \\
\text { cessationSANRT } \\
\text { formulation } \\
\text { allows for } \\
\text { flexible } \\
\text { dosingBy } \\
\text { prescription } \\
\text { onlyHand-to- } \\
\text { mouth use } \\
\text { mimics action of } \\
\text { smoking, } \\
\text { providing a } \\
\text { coping } \\
\text { mechanism for } \\
\text { conditioned } \\
\text { smoking cues }\end{array}$ & $\begin{array}{l}\text { Mouth and } \\
\text { throat irritation, } \\
\text { cough }\end{array}$ & $\begin{array}{l}\text { Pregnancy category DUse with caution in } \\
\text { acute cardiovascular conditions, such as } \\
\text { recent AMI; however, risk-benefit ratio may } \\
\text { be favorable in those patients who continue } \\
\text { to smoke }\end{array}$ & $\begin{array}{l}\text { 6-16 10-mg } \\
\text { cartridges/day for } \\
12 \text { wk; taper } \\
\text { dosage over next } \\
\text { 6-12 wkEach } \\
\text { cartridge delivers } \\
4 \text { mg of nicotine }\end{array}$ \\
\hline $\begin{array}{l}\text { Nicotine } \\
\text { lozenge }\end{array}$ & $\begin{array}{l}\text { FDA-approved } \\
\text { for smoking } \\
\text { cessationSANRT } \\
\text { formulation } \\
\text { allows for } \\
\text { flexible } \\
\text { dosingAvailable } \\
\text { OTC }\end{array}$ & $\begin{array}{l}\text { Mouth and } \\
\text { throat irritation, } \\
\text { hiccoughs }\end{array}$ & $\begin{array}{l}\text { Pregnancy category DUse with caution in } \\
\text { acute cardiovascular conditions, such as recent } \\
\text { AMI; however, risk-benefit ratio may be } \\
\text { favorable in those patients who continue to } \\
\text { smoke }\end{array}$ & $\begin{array}{l}\text { Patients who } \\
\text { smoke their first } \\
\text { cigarette within } 30 \\
\text { min of awakening } \\
\text { should use 4-mg } \\
\text { lozenges; others } \\
\text { should use the } 2 \text { - } \\
\text { mg dose } 1 \text { lozenge } \\
\text { every } 1 \text { to } 2 \text { h for } \\
\text { weeks } 1 \text { to } 6 \text {; } 1 \\
\text { lozenge every } 2 \text { to } \\
4 \text { h for weeks } 7 \text { to } \\
9 ; 1 \text { lozenge every } \\
4 \text { to } 8 \text { h for weeks } \\
10 \text { to } 12\end{array}$ \\
\hline
\end{tabular}




\begin{tabular}{|c|c|c|c|c|}
\hline Medication & Comments & $\begin{array}{l}\text { Most Common } \\
\text { Adverse Events }\end{array}$ & Contraindications/Precautions & Dosage \\
\hline $\begin{array}{l}\text { Nicotine nasal } \\
\text { spray }\end{array}$ & $\begin{array}{l}\text { FDA-approved } \\
\text { for smoking } \\
\text { cessationSANRT } \\
\text { formulation } \\
\text { allows for } \\
\text { flexible } \\
\text { dosingBy } \\
\text { prescription } \\
\text { onlyFastest } \\
\text { delivery system } \\
\text { for NRT, which } \\
\text { is useful for } \\
\text { rapid relief of } \\
\text { withdrawal } \\
\text { symptoms } \\
\text { (especially in } \\
\text { heavy smokers) }\end{array}$ & $\begin{array}{l}\text { Runny nose, } \\
\text { throat and nasal } \\
\text { irritation, } \\
\text { coughSide } \\
\text { effects usually } \\
\text { resolve after } 3 \\
\text { days }\end{array}$ & $\begin{array}{l}\text { Pregnancy category DUse with caution in } \\
\text { acute cardiovascular conditions, such as } \\
\text { recent AMI; however, risk-benefit ratio may } \\
\text { be favorable in those patients who continue } \\
\text { to smoke }\end{array}$ & $\begin{array}{l}1 \text { or } 2 \text { 0.5-mg } \\
\text { doses in each } \\
\text { nostril hourly for } \\
\text { 3-6 mo; taper } \\
\text { doses over } 4-6 \text { wk }\end{array}$ \\
\hline
\end{tabular}

The above table (Table 2) summarizes the indication, side effects, contraindication and dosage of different NRT products approved by Food and Drug Administration (FDA).

NRT appears safe in most patients, including those with CVD with stable angina. The safety of NRT has not been studied in patients with unstable angina or myocardial infarction within 2 weeks of planned treatment. ${ }^{15}$ Thus, for those inpatients with nicotine dependence admitted for acute coronary syndrome (ACS), NRTs should be used with caution. Unlike smoking, NRT does not increase the coagulability of blood or expose a patient to $\mathrm{CO}$ or oxidizing gases that damage endothelium. ${ }^{2}$ Despite the vasoconstrictor effects of nicotine, studies have failed to demonstrate an increased risk with the use of NRT in patients with CVD. The benefit of NRT appears to outweigh the risk for cardiovascular patients who continue to smoke.

In a randomized controlled trial (RCT), the results of 4 NRT products were compared. After 12 weeks of therapy, efficacy was similar (20-24\%) but the compliance varied among the groups widely, with the highest use noted in the patch (82\%), intermediate in the gum (36\%), and lowest in nasal spray (15\%) and vapour inhaler (11\%). The expected 12-month abstinence for NRT is $10-16 \% .{ }^{11}$ Combining NRT products such as the patch with gum or nasal spray was associated with higher cessation rates.
Most smokers perceive NRT as less satisfying than smoking cigarettes. This is due to:

1) Slower delivery of nicotine.

2) It only partially addresses the reinforcing effects of smoking that are not associated with nicotine.

For these reasons, NRT has been shown to be less liable for abuse and low dependence potential ${ }^{32}$. Moreover, there is no evidence of withdrawal discomfort when patients discontinue NRT use.

\section{Varenicline:}

Varenicline is the most recently FDA approved agent for smoking cessation and has been included in the DHHS guidelines for the treatment of tobacco dependence. ${ }^{8}$

Nicotine dependence is believed to be mediated by activation of $\alpha 4 \beta 2$ nicotinic acetylcholine receptor in the ventral tegmental area of the brain, and the $\alpha 4 \beta 2$ receptor density has been proven to be much higher in smokers. ${ }^{28,18}$ As a non-nicotinic partial agonist of the $\alpha 4 \beta 2$ nicotinic acetylcholine receptors, varenicline binding leads to partial stimulation of receptor-mediated release of dopamine in the reward centre and competitive inhibition of receptor binding by nicotine delivered from cigarettes. As a result varenicline suppresses the symptoms of nicotine withdrawal and reduces the pharmacologic reward from cigarette smoking. ${ }^{4}$ The following figure (Fig. 2) shows the mechanism of action of varenicline. 


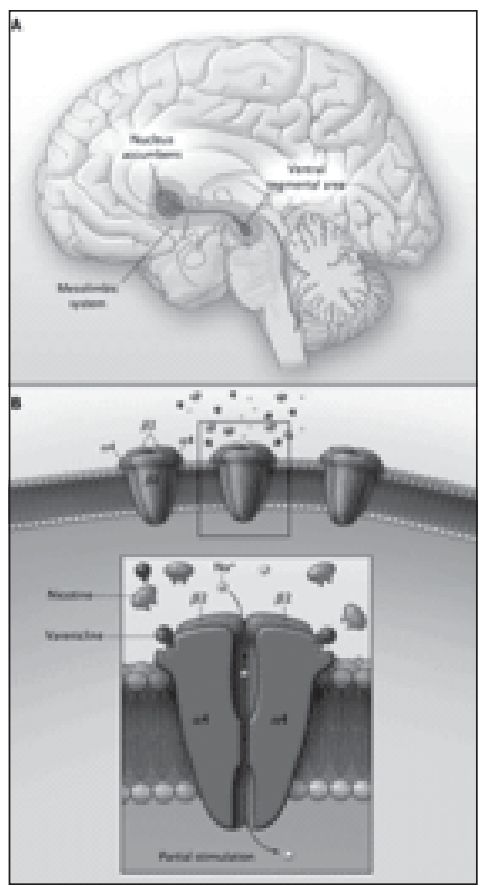

Fig.-2: The Actions of Nicotine and Varenicline in the Brain. (Slater et al., 2003)

Panel A: The principal site of nicotine action in the brain is the mesolimbic system. Nicotine stimulates dopaminergic neurons located in the ventral tegmental area, increasing dopamine release in the nucleus accumbens. Nicotine interacts with nicotinic acetylcholine receptors located in the mesolimbic system and elsewhere.

Panel B: The highest-affinity nicotinic acetylcholine receptors consist of two $\alpha 4$ subunits and three $\beta 2$ subunits. Nicotine binds to and causes a conformational change in the $\alpha 4 \beta 2$ nicotinic acetylcholine receptor, increasing sodium $\left(\mathrm{Na}^{+}\right)$influx. Varenicline is a partial agonist of the $\alpha 4 \beta 2$ nicotinic acetylcholine receptor that causes partial stimulation while it competitively inhibits nicotine binding.

Table-III

Dose and duration of treatment of varenicline

\begin{tabular}{ll}
\hline Dose & Duration \\
\hline $0.5 \mathrm{mg}$ daily for 3 days , then & 12 weeks \\
$0.5 \mathrm{mg}$ bid for 4days, then & \\
$1 \mathrm{mg}$ bid from day 8 for 12 weeks & \\
\hline
\end{tabular}

Table 3: The above table (table 3) shows the dose and total duration of treatment of varenicline. The 1 -week dose adjustment period reduces nausea as compared with initial therapy at $1 \mathrm{mg}$ twice daily. ${ }^{21}$
The following table shows the adverse effects of varenicline compared with placebo.

Table 4 shows that $12 \%$ subjects discontinued varenicline due to treatment related adverse events in RCTs at a dose of $1 \mathrm{mg}$ twice daily. Adverse events reported in 5\% or more of subjects are included. Other gastrointestinal effects were vomiting, constipation, diarrhea, flatulence and dyspepsia. The numbers are expressed in percentage ${ }^{14,10}$.

Table-IV

\begin{tabular}{lcc}
\hline Adverse effect & Varenicline & Placebo \\
\hline Nausea & 35.8 & 11.2 \\
Insomnia & 22 & 12.7 \\
Abnormal dreams & 14.4 & 5 \\
Headache & 16.8 & 14.3 \\
Other gastrointestinal effects & 22.5 & 11.8 \\
$\begin{array}{l}\text { Discontinuation of varenicline } \\
\text { due to treatment related }\end{array}$ & 12 & 8.1 \\
adverse event & & \\
\hline
\end{tabular}

The overall incidence of adverse events leading to discontinuation of varenicline is similar to that observed with placebo. The ceiling effect seen with partial agonists (i.e., increasing the dose beyond a certain point does not increase the effect) suggests a low potential for abuse with varenicline. ${ }^{20,22}$

In 2006, Food and Drug Administration (FDA) advised consumers and physicians about psychiatric symptoms while using varenicline but provided no data about similar events among other smokers to derive a denominator. Similar events were not appreciated in the approval study and probably underscore the fact that most cessation trials exclude patients with any prior history of psychiatric condition or simultaneous use of psychologically active drugs. ${ }^{14,30}$ The Institute for Safe Medication Practice has recommended physicians exercise caution in the use of varenicline in whom the risk of accident is high, such as those operating mass transit vehicles, trains, planes, or heavy machinery or life-sustaining devices. ${ }^{29}$

The meta-analysis by Cochrane review found seven trials of varenicline compared with placebo for smoking cessation; three of these also included a bupropion experimental arm. It also found one open-label trial comparing varenicline with nicotine replacement therapy. The pooled risk ratio (RR) for continuous abstinence at six months or longer for varenicline versus placebo was 2.33 (95\% confidence interval [CI] 1.95 to 2.80). The pooled RR for varenicline versus bupropion at one year 
was 1.52 (95\% CI 1.22 to 1.88). The RR for varenicline versus NRT at one year was 1.31 (95\% CI 1.01 to 1.71$){ }^{3}$

Varenicline increased the chances of successful long-term smoking cessation between two- and threefold compared with pharmacologically unassisted quit attempts. More participants quit successfully with varenicline than with bupropion. Two open-label trial of varenicline versus nicotine replacement therapy demonstrated a modest benefit of varenicline. ${ }^{26}$

In another meta-analysis of available pharmacological therapies for smoking cessation, all therapies were better than placebo. In the trials of varenicline that included bupropion in the controlled arm, varenicline was found superior (OR, 2.18; CI 1.09-4.08). ${ }^{30}$

Recently a multicenter, placebo-controlled RCT compared the efficacy and safety of varenicline in smokers with stable cardiovascular disease. The primary end point was CO confirmed continuous abstinence rate for weeks 9 through 12 (last 4 weeks of treatment). The continuous abstinence rate was higher for varenicline than placebo during weeks 9 through 12 (47\% versus 13.9\%; OR, 6.11 (95\% CI 1.93 to 5.11$)$ and weeks 9 through 52 (19.2\% versus $7.2 \%$; OR, 3.14 (95\% CI 1.93 to 5.11). The varenicline and placebo groups did not differ significantly in cardiovascular mortality, all-cause mortality, cardiovascular events or serious adverse events. ${ }^{23}$

\section{Conclusion:}

Smoking is best regarded as a chronic disease that requires a long-term management strategy, rather than a quick solution. ${ }^{31}$ Smoking cessation has been valued as the single most important step that smokers can take to enhance the length and quality of their lives. ${ }^{1}$ Most smokers mistakenly believe that stopping smoking is purely a matter of willpower and remain unaware of effective treatments to promote quitting. Smokers trying to quit have to cope with psychological, behavioral, and physical aspects of tobacco dependence. Smokers develop nicotine dependence that resembles other addictions, and may require multiple attempts and long-term treatment to sustain abstinence.

Currently approved $1^{\text {st }}$-line agents include NRT, which is available in different formulations; bupropion, an atypical antidepressant, and varenicline, a partial agonist of the $\alpha 4 \beta 2$ nicotinic acetylcholine receptor receptor. All therapies are better than placebo. The multiple formulations of NRT offer smokers a choice in the route of administration, which may have a positive influence on adherence to treatment. Combination of nicotine patch with gum, inhaler, or nasal spray was more efficacious than the use of any of these products alone. ${ }^{8}$

Varenicline was found superior to bupropion and NRT in clinical trials. More methodologically rigorous studies comparing varenicline and NRT are needed to make any judgement about their comparative efficacy.

Both NRT and varenicline have a benign adverse event profile, with a low rate of discontinuation due to adverse events. Their safety profile appears to outweigh the risk for cardiovascular patients who continue to smoke. However their safety has not been studied in patients with acute coronary syndrome (unstable angina or myocardial infarction) within 2 weeks of planned treatment. Therefore they should be used with caution in patients with nicotine dependence admitted for ACS.

The long-term benefit of smoking cessation on cardiovascular risk suggests a $36 \%$ reduction in mortality risks. ${ }^{5}$ The reduction in mortality due to CVD exceeds the benefits of other preventative therapies such as use of statins (29\%), aspirin (15\%), and $\beta$-blockers (23\%). ${ }^{22}$ Therefore, assistance with smoking cessation is a cost-effective intervention that is underused by health professionals. ${ }^{6}$ For physicians and health care system alike, the challenge is implementing effective treatment in routine medical practice.

\section{References :}

1. American Cancer Society. (2006) Guide to Quitting Smoking. Atlanta, GA, .

2. Benowitz, N.L. and Gourlay, S.G. (1997) Cardiovascular toxicity of nicotine: implications for nicotine replacement therapy. J Am Coll Cardiol, 29, 1422-31.

3. Cahill, K. \& Stead, L.F. and Lancaster, T. (2009) Nicotine receptor partial agonists for smoking cessation (Review). [Online] Available from: http://www.thecochranelibrary.com [Accessed 0504-2010].

4. Coe, J. W., Brooks, P. R. \& Vetelino, M. G. et al. (2005) Varenicline: an alpha4 beta2 nicotinic receptor partial agonist for smoking cessation. J Med Chem, 48, 3474-7.

5. Critchley, J.A. and Capewell, S. (2003) Mortality risk reduction associated with smoking cessation in patients with coronary heart disease: a systematic review. JAMA, 290, 86-97.

6. Cromwell, J., Bartosch, W. J. \& Fiore, M. C. et al. (1997) Costeffectiveness of the clinical practice recommendations in the AHCPR guideline for smoking cessation. JAMA, 278, 1759-66.

7. Environmental Protection Agency. (1992) Respiratory health effects of passive smoking: lung cancer and other disorders. Washington DC, Office of Health and Environmental Assessment.

8. Fiore, M. C., Bailey, W. C. \& Cohen, S. J. et al. (2008) Treating Tobacco Use and Dependence: Clinical Practice Guideline. Rockville, MD, US Dept of Health and Human Services, Public Health Service, 
9. Garrett, B. E. \& Rose, C. A. and Hennigfield, J.E. (2001) Tobacco addiction and pharmacological interventions. Exper Opin Pharmacother, 10, 1545-1555.

10. Gonzalez, D., Rennard, S. I. \& Nides, M. et al. (2006) Varenicline, an alpha4 beta2 nicotinic acetylcholine receptor partial agonist, vs sustained-release bupropion and placebo for smoking cessation: a randomized controlled trial. JAMA, 296, 47-55.

11. Hajek, P., West, R. \& Foulds, J. et al. (1999) Randomized comparative trial of nicotine polacritex, a transdermal patch, nasal spray, and an inhalor. Arch Int Med, 159, 2033-2038.

12. Henningfield, E. (1995) Nicotine medications for smoking cessation. N Eng J Med, 333, 1196-1203.

13. Independent Scietific Committee on Smoking and Health (ISCSH). (1988) Fourth Report of the Independent Scientific Committee on Smoking and Health (Chairman Sir Peter Froggatt). London, HMSO.

14. Jorenby, D. E., Hays, J. T. \& Rigotti, N.A. et al and Varenicline Phase 3 Study Group. (2006) Efficacy of varenicline, an alpha4beta2 nicotinic acetylcholine receptor partial agonist, vs placebo or sustained-release bupropion for smoking cessation: a randomized controlled trial. JAMA, 296, 56-63.

15. Joseph, A. M., Norman, S. M., Ferry, L. H. \& et al. (1996) The safety of transdermal nicotine as a $\mathrm{n}$ aid to smoking cessation in patients with cardiac disease. N Eng J Med, 335, 1792-1798.

16. Mackay, J. \& Mensah, G. (2004) WHO Atlas of Heart Disease and Stroke. Geneva, Nonserial WHO Publication.

17. McIntyre, D. (2004) Lifestyle management: smoking. In: Lindsay, G.M. \& Gaw, A. (ed.) Coronary Heart Disease Prevention A Handbook for the Health-Care Team. ISBN 0443071179 series. 2nd edition. China, Churchill Livingstone, pp. 131-158.

18. Mukhin, A. G., Kimes, A. S. \& Chefer, S. I. et al. (2008) Greater nicotinic acetylcholine receptor density in smokers than in nonsmokers: a PET study with 2-18F-FA-85380. JNM, 49, 16281635.

19. Nides, M. (2008) Update on Pharmacologic Options for Smoking Cessation Treatment. The American Journal of Medicine, 121 (4), S20-S31.

20. Ohlsen, R.I. and Pilowsky, L.S. (2005) The place of partial agonism in psychiatry: recent developments. J Psychopharmacol, 19, 408-413.
21. Oncken, C., Gonzalez, D. \& Nides, M. et al. (2006) Efficacy and safety of the novel selective nicotinic acetylcholine receptor partial agonist, varenicline, for smoking cessation. Arch Intern Med, 166, 1571-7.

22. Pignone, M. \& Phillips, C. and Mulrow, C. (2000) Use of lipid lowering drugs for primary prevention of coronary heart disease: a meta-analysis of randomized trials. BMJ, 321, 983-986.

23. Rigotti, N. A., Andrew, L. \& Pipe, C. M. et al. (2010) Efficacy and Safety of Varenicline for Smoking Cessation in Patients With Cardiovascular Disease. A Randomized Trial. Circulation, 121 (2), 188-190.

24. Royal College of Physicians (RCP). (1983) Health or smoking. London, Pitman.

25. Slater, Y. E., Houlihan, L. M. \& Maskell, P. D. et al. (2003) Halogenated cystisine derivatives as agonists at human neuronal nicotinic acetylcholine receptor subtypes. Neuropharmacology, 44, 503-15.

26. Stapleton, J. A., Watson, L. \& Spirling, L. I. et al. (2008) Varenicline in the routine treatment of tobacco dependence: a prepost comparison with nicotine replacement therapy and an evaluation in those with mental illness. Addiction, 103, 146-54.

27. Stead, L. F., Perera, R., Bullen, C. \& et al. (2008) Nicotine replacement therapy for smoking cessation (Review). [Online] Available from: http://www.thecochranelibrary.com [Accessed 0504-2010].

28. Tapper, E. R., Mckinney, S. L., Nashmi, E. et al \& 1999 World Health Organization-International Society of Hypertension. (2004) Nicotine activation of alpha 4 receptors: sufficient for reward, tolerance, and sensitization. Science, 306, 1029-1032.

29. The Institute for Safe Medication Practices. (2008) Strong safety signal seen for varenicline risks. E-Published, , .

30. US food and Drug Administration. (2008) Public health advisory: important impormation on Chantix (varenicline). Center for Drug evaluation and Research.

31. US Public Health Service report. (2000) A clinical practice guideline for treating tobacco use and dependence. JAMA, 283, 3244-54.

32. West, R., Hajek, P. \& Foulds, J. et al. (2000) A comparison of abuse liability and dependence potential of niotine patch, gum, spray and inhalor. Psychopharmacology (Berl), 149, 198-202. 